\title{
Pengaruh waktu layar terhadap praktik pemberian makan dengan regulasi diri pada perilaku makan anak
}

\section{Dini Mei Rasaningrum ${ }^{1}$ dan Sri Redatin Retno Pudjiati ${ }^{2}$}

\begin{abstract}
The development of self-regulation of eating is strongly influenced by feeding practice. In addition, a child's screen time has an effect on children eating behavior. The aim of this study was to determine whether screen time acts as a moderator to the relationship between feeding practice and the ability to self-regulation eating in preschool age. Method samples were 95 mothers who had children aged 3-6 years. Participants were chosen using convenient sampling. Data were analyzed using linear regression and sub-groups analysis with ANOVA factorial $2 \times 2$. Findings show that screen time doesn't a moderator of the relationship between restrictive feeding practice and self-regulation of eating. The conclusion is the restrictive feeding practice can interfere with children's self-regulation of eating abilities. However, the effect of screen time doesn't significantly contribute to moderating the relationship between restrictive feeding practice and children's self-regulation of eating.
\end{abstract}

\section{Keywords}

eating behavior, restrictive feeding practice, screen time, self-regulation of eating

\section{Pendahuluan}

Regulasi diri memiliki peranan penting dalam berbagai aspek pertumbuhan dan perkembangan anak, salah satunya perkembangan regulasi diri dalam praktik makan. Secara alami, anak sejak lahir memiliki kemampuan meregulasi makan sendiri untuk menyesuaikan antara asupan makan dengan kebutuhan tubuhnya. Namun, anak membutuhkan peran dari lingkungannya untuk membentuk pola makan. Pada tahapan usia prasekolah, kebiasaan makan anak dan pilihan makanan mulai berkembang dan muncul pada tahapan ini (Brown, 2011). Regulasi diri yang rendah pada perilaku makan sering muncul pada anak dengan kelebihan berat badan atau obesitas (Tan \& Holub, 2010). Jumlah anak balita di Indonesia yang mengalami kelebihan berat badan masih cukup banyak. Riset Kesehatan Dasar tahun 2018 menyebutkan sebanyak 8\% anak balita di Indonesia mengalami kegemukan (Kementerian Kesehatan RI, 2018). Interaksi antara orang tua atau pengasuh utama dan anak selama proses makan akan membentuk regulasi diri pada anak dalam perilaku makan (Frankel et al., 2012). Sehingga, orang tua atau pengasuh memiliki peranan besar dalam perkembangan regulasi diri pada perilaku makan anak.

Regulasi diri dalam praktik makan merupakan kemampuan anak untuk makan atau tidak makan sebagai respon dari sinyal lapar atau kenyang (Hughes et al., 2016). Sinyal lapar yang disebut respon lapar merupakan respon anak terhadap makanan, sedangkan sinyal kenyang disebut respon kenyang yang merupakan respon terhadap rasa kenyang yang dirasakan anak. Respon lapar dan kenyang merupakan dua kriteria untuk mengukur regulasi diri dalam praktik makan pada anak (Hughes et al., 2015). Kemampuan meregulasi diri pada perilaku makan dipengaruhi oleh sinyal internal dalam diri anak dan aspek eksternal terkait pengaruh dari luar seperti interaksi saat proses pemberian makan oleh orang tua (Hughes et al., 2015). Aspek eksternal seperti faktor lingkungan sosial anak memberikan pengaruh dalam perilaku makan anak. Faktor lingkungan sosial ini dipengaruhi oleh praktik pemberian makan yang dilakukan oleh orang tua atau ibu sebagai pengasuh utama (Lafraire et al., 2016). Menurut teori ekologi Bronfenbrenner, ibu memiliki peran sebagai mikrosistem yang memiliki interaksi secara langsung dengan anak dan memengaruhi perkembangan anak (Santrock, 2014). Konsep ini juga berlaku pada perilaku makan anak. Interaksi ini berkaitan dengan praktik pemberian makan anak oleh ibu. Respon ibu terhadap ekspresi dari sinyal lapar dan kenyang anak juga berperan penting dalam membentuk regulasi diri anak dalam praktik makan. Sebagai pengasuh utama, ibu berperan utama dalam mendorong anak untuk mengonsumsi makanan sehat, membatasi makanan yang

\footnotetext{
${ }^{1,2}$ Fakultas Psikologi Universitas Indonesia
}

Korespondensi:

Sri Redatin Retno Pudjiati, Fakultas Psikologi, Universitas Indonesia, Depok, 16424, Indonesia

Email: retno-pj@ui.ac.id 
tidak sehat, dan memberikan contoh kepada anak berperilaku makan yang sehat (Blissett, 2011).

Praktik pemberian makan yang dilakukan oleh orang tua kepada anak dapat berdampak pada kemampuan anak untuk meregulasi diri dalam praktik makan. Salah satu praktik pemberian makan yang memiliki dampak pada regulasi diri dalam praktik makan adalah praktik pemberian makan yang bersifat membatasi akses atau membatasi jenis maupun jumlah makanan yang dikonsumsi (Blissett, 2011). Sebuah studi menyebutkan bahwa ibu yang menerapkan praktik pemberian makan yang bersifat membatasi memiliki persepsi bahwa praktik pemberian makan yang mereka lakukan akan berhasil seperti yang mereka harapkan yaitu dapat membatasi jenis-jenis makanan yang mereka batasi (Vollmer \& Baietto, 2017). Namun, hal ini bertolak belakang dengan beberapa penelitian lain yang menyimpulkan bahwa praktik pemberian makan yang bersifat membatasi membuat konsumsi anak terhadap makanan yang dibatasi semakin meningkat (Vollmer \& Baietto, 2017; Morrison et al., 2013).

Di Indonesia, penelitian seputar praktik pemberian makan pada anak usia dini masih terbatas. Studi oleh Rifani et al. (2019) menyimpulkan bahwa jumlah partisipan yang menerapkan praktik pemberian makan yang bersifat membatasi pada anak berjumlah kurang dari $2 \%$. Sedangkan praktik pemberian makan oleh ibu didominasi dengan divert attention atau pemberian makan yang dilakukan bersama kegiatan lain seperti menonton televisi atau video. Namun, setelah dilakukan analisis kualitatif melalui wawancara secara mendalam dan diskusi kelompok diperoleh bahwa praktik pemberian makan yang bersifat membatasi ini ternyata banyak dilakukan oleh para partisipan. Hasil wawancara dengan partisipan menyimpulkan bahwa praktik pemberian makan yang bersifat membatasi yang bertujuan untuk menjaga kesehatan anak paling banyak dilakukan oleh para ibu. Sedangkan, praktik pemberian makan yang bersifat membatasi yang bertujuan untuk menjaga berat badan anak tidak banyak dilakukan oleh ibu (Rifani et al., 2019). Hal ini dapat dipengaruhi oleh budaya dan nilai-nilai yang ada di masyarakat yang menganggap anak dengan postur tubuh gemuk memiliki kesejahteraan yang lebih baik dan orang tua lebih menyukai anak-anak yang bertubuh gemuk daripada bertubuh kurus. Hal ini menunjukkan bahwa praktik pemberian makan yang bersifat membatasi yang dilakukan ibu-ibu di Indonesia masih belum konsisten. Faktor lain seperti pemberian media elektronik pada anak dapat dikaji lebih mendalam pengaruhnya terhadap regulasi diri dalam praktik makan anak. Praktik pemberian makan yang bersifat membatasi yang bertujuan menjaga kesehatan anak lebih banyak diterapkan oleh para ibu daripada yang bertujuan untuk menjaga berat badan anak. Padahal kedua praktik ini memiliki tujuan utama yang sama yaitu untuk membatasi makan anak. Kesenjangan yang terjadi di masyarakat pada praktik pemberian makan yang bersifat membatasi ini sangat menarik untuk diteliti lebih mendalam.

Pada era digital seperti sekarang ini penggunaan gawai pada anak menjadi hal yang sudah tidak asing lagi. Layar televisi, komputer, telepon genggam, maupun tablet menjadi media yang umum diberikan orang tua kepada anaknya. Laporan dari The Asian Parent Insight (2014) menyebutkan bahwa sebanyak $98 \%$ orang tua di Asia Tenggara membolehkan anak menggunakan gawai. Anak usia 5-6 tahun menghabiskan waktu untuk menonton televisi atau menggunakan gawai selama lebih dari dua jam setiap hari memiliki risiko mengalami kegemukan lebih besar apabila dibandingkan dengan durasi waktu layar kurang dari dua jam per hari (Pavilianingtyas, 2017). Saat ini, kualitas makan anak juga dipengaruhi oleh waktu layar yang berdampak pada perilaku makan yang tidak sehat pada anak (Avery et al., 2017; Pearson et al., 2018). Studi pada anak usia 5-6 tahun di Semarang juga menemukan bahwa durasi waktu layar menjadi salah satu faktor penyebab masalah gizi pada anak yaitu kegemukan. Risiko kegemukan meningkat dapat diakibatkan konten media yang dilihat anak saat menggunakan gawai seperti iklan makanan yang tidak sehat mempengaruhi perilaku makan anak dan menurunnya aktivitas fisik. Ini didukung oleh sebuah data yang menyebutkan bahwa 50\% iklan yang ditayangkan pada siaran televisi merupakan iklan makanan untuk anak-anak. Studi oleh Subardjo et al. (2013) membuktikan bahwa anak yang terpapar iklan makanan cepat saji cenderung lebih memilih dan meningkatkan konsumsi makanan cepat saji yang diiklankan. Studi lainnya membuktikan bahwa regulasi diri dalam praktik makan anak menurun setelah diberikan paparan iklan makanan tidak sehat selama tiga hari (Norman et al., 2018). Berkaitan dengan semakin meningkatnya penggunaan gawai pada anak, maka perilaku ini dapat dikaji lebih jauh terkait seberapa besar pengaruhnya dalam hubungan antara praktik pemberian makan yang bersifat membatasi yang banyak diterapkan para ibu dengan regulasi diri dalam praktik makan.

Ketidakmampuan meregulasi diri pada perilaku makan dapat dipengaruhi faktor lingkungan seperti waktu layar dan praktik pemberian makan oleh ibu. Praktik pemberian makan yang bersifat membatasi dapat memberikan pengaruh yang berbeda pada regulasi diri dalam praktik makan. Hasil observasi oleh Farrow et al. (2018) menunjukkan bahwa praktik pemberian makan yang bersifat membatasi ini dapat menghambat pembentukan regulasi diri dalam praktik makan pada anak. Di Indonesia, praktik pemberian makan yang bersifat membatasi masih belum konsisten dan pemberian gawai oleh orang tua kepada anak sebagai salah satu cara agar anak makan dengan tenang menjadi hal yang menarik untuk diteliti. Prevalensi yang tinggi dalam pemberian gawai oleh orang tua di Indonesia sejalan dengan temuan sebelumnya yaitu kebanyakan dari ibu sering memberikan gawai ketika anak sedang makan (Rifani et al., 2019). Kesenjangan yang muncul karena kurang konsistensinya penerapan praktik 
pemberian makan yang bersifat membatasi dan ditambah fenomena meningkatnya pemberian gawai pada anak dapat berdampak pada kemampuan regulasi diri dalam praktik makan anak. Peneliti menduga bahwa waktu layar dapat memperlemah hubungan antara praktik pemberian makan yang bersifat membatasi oleh ibu dengan regulasi diri dalam praktik makan anak. Berdasarkan hal tersebut maka ada dua hipotesis yang ditegakkan. Pertama, waktu layar anak secara signifikan dapat memoderasi hubungan antara praktik pemberian makan yang bersifat membatasi oleh ibu dengan respon kenyang anak. Hipotesis kedua yaitu waktu layar anak secara signifikan memoderasi hubungan antara praktik pemberian makan yang bersifat membatasi dengan respon lapar anak. Hasil dari penelitian ini dapat membantu peneliti dalam menyusun strategi terkait praktik pemberian makan untuk membentuk pola makan sehat untuk anak usia prasekolah.

\section{Metode}

Jenis penelitian ini merupakan penelitian kuantitatif dengan desain penelitian korelasional. Variabel kriteria dari penelitian ini adalah regulasi diri dalam praktik makan dari anak usia prasekolah yang direpresentasikan oleh dua kriteria yaitu respon kenyang dan respon lapar. Praktik pemberian makan yang bersifat membatasi sebagai prediktor. Sedangkan, waktu layar anak sebagai moderator. Partisipan dipilih menggunakan non-probability sampling dengan teknik convenient sampling. Karakteristik sampel yaitu ibu yang memiliki anak usia 3-6 tahun yang memberikan gawai pada anaknya. Penentuan jumlah pasrtisipan menggunakan analisis G-Power. Berdasarkan perhitungan G-Power, penelitian ini membutuhkan jumlah sampel sebanyak 77 partisipan. Adapun partisipan yang terlibat dalam penelitian ini sejumlah 95 orang sesuai dengan kriteria yang telah di ajukan. Data yang digunakan dalam penelitian ini adalah data primer yang diperoleh langsung dari partisipan dengan menggunakan kuesioner yang diisi oleh ibu.

Alat ukur atau instrumen yang digunakan dalam penelitian ini terdiri dari 3 kuesioner. Pertama, Comprehensive Feeding Practices Questionnaire (CFPQ) yang mengukur berbagai jenis praktik pemberian makan oleh ibu. Dimensi praktik pemberian makan yang diukur dalam $C F P Q$ antara lain adalah encourage balance and variety, environment, food as reward, involvement, modelling, monitoring, pressure, restriction for health and weight, dan teaching about nutrition (Musher-Eizenman \& Holub, 2007). Pada penelitian ini, pengukuran praktik pemberian makan yang bersifat membatasi menggunakan dimensi restriction for health and weight dari CFPQ. Skala pengukuran menggunakan skala Likert yaitu untuk item nomor 1 sampai 13 menggunakan skala tidak pernah, jarang, sering, dan selalu. Sedangkan item nomor 14 sampai 49 menggunakan skala tidak setuju, agak tidak setuju, agak setuju, dan setuju. Kuesioner ini telah diadaptasi oleh peneliti ke dalam Bahasa Indonesia dan telah dilakukan uji coba pada 30 partisipan. Kuesioner ini memiliki $\alpha=0.81$. Kuesioner yang diadaptasi telah dilakukan face validity oleh pakar dan perbaikan kosa kata yang menyesuaikan konteks. Kuesioner dinyatakan secara valid dan reliabel dapat mengukur praktik pemberian makan yang bersifat membatasi.

Alat ukur kedua adalah kuesioner untuk mengukur waktu layar anak yang menggunakan adaptasi dari $A S A Q$ (Adolescent Sedentary Activity Questionnaire). Tujuan dari penggunaan alat ukur ini adalah untuk mengetahui durasi waktu layar anak selama satu minggu dalam satuan jam. Alat ukur ini memiliki reliabilitas yang baik dan berguna untuk mengukur perilaku yang banyak dilakukan sambil duduk ini. Selain itu, alat ukur ini tidak terikat dengan usia dan memiliki sedikit perbedaan pada pengukuran reliabilitas pada kelompok usia yang berbeda (Hardy et al., 2007). Alat ukur ini telah diadaptasi sesuai dengan kriteria sampel yaitu usia 3-6 tahun. Kuesioner ini telah dilakukan face validity dan dinyatakan secara valid dapat mengukur durasi anak menggunakan gawai.

Ketiga, regulasi diri dalam praktik makan pada anak usia 3-6 tahun diukur dengan menggunakan Children's Eating Behaviour Questionnaire (Wardle et al., 2001). Kuesioner $C E B Q$ merupakan alat ukur multidimensi yang diisi oleh ibu dan digunakan untuk mengukur perilaku makan anak. Kuesioner ini memiliki tujuh dimensi yang terdiri dari 5 item untuk dimensi satiety responsiveness, 5 item untuk dimensi food responsiveness, 5 item untuk dimensi emotional overeating, 3 item untuk dimensi emotional undereating, 4 item untuk dimensi enjoyment of food, 3 item untuk dimensi desire to drink, 4 item untuk dimensi slowness in eating, dan 6 item untuk dimensi food fussiness (Wardle et al., 2001).

Pada penelitian ini, regulasi diri dalam praktik makan diukur menggunakan dua dimensi yaitu satiety responsiveness atau respon kenyang dan food responsiveness atau respon lapar. Kedua dimensi ini bertujuan untuk mengukur persepsi ibu terkait kemampuan anak dalam meregulasi diri dalam praktik makan. Skala pengukuran pada alat ukur ini terdiri dari empat Likert scale yaitu tidak pernah, jarang, sering, dan selalu. Oleh karena regulasi diri dalam praktik makan anak merupakan variabel kriteria yang diukur dengan alat ukur multidimensional. Maka, hasil analisis menghasilkan dua hasil yang merepresentasikan masingmasing dimensi yaitu respon kenyang $\left(Y_{1}\right)$ dan respon lapar $\left(Y_{2}\right)$. Adaptasi dari alat ukur ini telah dilakukan uji coba pada 30 partisipan. Kuesioner ini memiliki nilai $\alpha=$ 0.74. Uji validitas menggunakan face validity oleh pakar dan selama proses percobaan ada perubahan beberapa kata yang disesuaikan dengan konteks. Hasilnya menyatakan bahwa kuesioner ini secara valid dan reliabel mampu mengukur regulasi diri dalam praktik makan anak.

Ketiga kuesioner ini diisi oleh ibu dalam waktu yang bersamaan baik secara langsung atau melalui daring. Distribusi kuesioner melalui daring diberikan dalam bentuk google form. Sebelum pengisian kuesioner, ibu diminta kesediannya terlebih dahulu atas keikutsertaan 
Tabel 1. Data variabel praktik pemberian makan, waktu layar, regulasi diri dalam praktik makan

\begin{tabular}{lcccc}
\hline Variabel & $M$ & $s$ & Nilai Minimal & Nilai Maksimal \\
\hline Praktik pemberian makan yang bersifat membatasi & 1.60 & 0.61 & 1.00 & 3.70 \\
Waktu layar (jam) & 3.70 & 2.60 & 0.04 & 11.7 \\
Regulasi diri dalam praktik makan & & & & \\
$\quad$ Respon kenyang $\left(Y_{1}\right)$ & 2.40 & 0.50 & 1.40 & 3.40 \\
$\quad$ Respon lapar $\left(Y_{2}\right)$ & 1.95 & 0.40 & 1.20 & 3.40 \\
\hline
\end{tabular}

Catatan. Jumlah sampel keseluruhan yang diperoleh sebanyak 95 partisipan.

dalam penelitian ini dengan memberikan informed consent. Penelitian ini telah mendapatkan persetujuan kaji etik dari Komite Kaji Etik Fakultas Psikologi Universitas Indonesia. Analisis statistik dalam penelitian ini terdiri dari beberapa tahapan. Analisis awal menggunakan analisis regresi linier dan analisis PROCESS model I untuk mengetahui pengaruh antar variabel dan menentukan jenis variabel yang terdapat penelitian ini (Hayes, 2018). Setelah peneliti menemukan jenis variabel moderator dalam penelitian ini yaitu homologizer moderator maka langkah selanjutnya adalah melakukan analisis moderasi dilanjutkan dengan metode sub-kelompok.

Metode analisis sub-kelompok bertujuan untuk mengidentifikasi ada tidaknya variabel homologizer moderator (Ghozali, 2016). Analisis ini dipilih sebagai pendekatan alternatif untuk menguji ada atau tidaknya moderator dengan menguji bentuk hubungan regresi untuk setiap subkelompok. (Sugiyono, 2004; Ghozali, 2016). Metode analisis moderasi dengan sub-kelompok ini dilakukan dengan membagi sampel menjadi dua sub-kelompok atas dasar variabel moderator. Pembagian dua kelompok dapat dilakukan dengan mengacu pada median, sehingga diperoleh dua kelompok sampel dengan nilai di atas dan di bawah median. Menurut Hayes (2018), metode yang tepat untuk melakukan analisis sub-kelompok pada penelitian ini adalah analisis ANOVA faktorial 2x2.

\section{Hasil}

Jumlah total partisipan sebanyak 95 partisipan. Berdasarkan Tabel 1 skor rata-rata orang tua menerapkan praktik pemberian makan yang bersifat membatasi sebesar $1.6(M=1.6, s=0.6)$. Durasi waktu layar anak rata-rata 3.7 dalam satuan jam setiap harinya $(M=3.7, s=2.6)$. Variabel regulasi diri dalam praktik makan memiliki dua dimensi yaitu respon kenyang $(M=2.4, s=0.5)$ dan respon lapar $(M=1.95, s=0.4)$.

Sebelum melakukan analisis moderasi, peneliti menentukan jenis dari variabel moderator yang terdapat pada penelitian ini dengan mengolah data menggunakan analisis regresi linier. Hasil dari analisis regresi awal dapat dilihat dari Tabel 2. Hasil analisis regresi terdiri dari langkah 1, 2, 3, dan 4. Langkah pertama menggambarkan pengaruh praktik pemberian makan yang bersifat membatasi terhadap respon kenyang $\left(Y_{1}\right)$ dan respon lapar $\left(Y_{2}\right)$. Langkah kedua menunjukkan pengaruh dari waktu layar terhadap respon kenyang $\left(Y_{1}\right)$ dan respon lapar $\left(Y_{2}\right)$. Langkah ketiga menunjukkan pengaruh praktik pemberian makan yang bersifat membatasi dan waktu layar terhadap respon kenyang $\left(Y_{1}\right)$ dan respon lapar $\left(Y_{2}\right)$. Dan, pada langkah keempat menunjukkan pengaruh praktik pemberian makan yang bersifat membatasi, waktu layar, dan interaksi antara praktik pemberian makan yang bersifat membatasi dengan waktu layar terhadap respon kenyang $\left(Y_{1}\right)$ dan respon lapar $\left(Y_{2}\right)$.

\section{Respon Kenyang $\left(Y_{1}\right)$}

Hasil dari analisis regresi (Tabel 2) langkah 1 menunjukkan hasil yang signifikan $F(1,94)=6.37, p=0.013, R^{2}=$ 0.064. Hal ini menjelaskan bahwa respon kenyang dapat dijelaskan oleh praktik pemberian makan yang bersifat membatasi sebesar $6.4 \%$ dan sisanya sebesar 93.6\% dapat dijelaskan oleh sebab-sebab lain di luar model. Pada analisis regresi langkah 2 menunjukkan hasil yang tidak signifikan $F(1,94)=0.61, p=0.44, R^{2}=$ 0.007 , yang artinya waktu layar tidak berpengaruh secara signifikan terhadap respon kenyang. Analisis regresi langkah 3 menunjukkan hasil yang signifikan $F(2,92)=3.16, p=0.047, R^{2}=0.064$. Hasil ini dapat digunakan untuk memprediksi bahwa praktik pemberian makan yang bersifat membatasi dan waktu layar secara bersama-sama berpengaruh terhadap respon kenyang $\left(Y_{1}\right)$. Sedangkan interaksi antara praktik pemberian makan yang bersifat membatasi dengan waktu layar terhadap respon kenyang $\left(Y_{1}\right)$ menunjukkan hasil yang tidak signifikan. Hal ini dibuktikan dengan nilai $F(3,91)=2.4, p=$ $0.07, R^{2}=0.07$, yang artinya tidak adanya interaksi antara praktik pemberian makan yang bersifat membatasi dengan waktu layar.

Hasil dari analisis awal ini membuktikan adanya homologizer moderator dengan dibuktikan tidak ada hubungan antara variabel moderator dengan variabel prediktor dan tidak adanya interkasi yang terjalin antara variabel prediktor dengan moderator. Jenis variabel ini mempengaruhi kekuatan hubungan antara variabel prediktor dengan kriteria. Maka, untuk melihat seberapa besar kekuatan hubungan antara variabel prediktor dengan kriteria dibutuhkan analisis moderasi lanjutan yaitu analisis sub-kelompok dengan ANOVA faktorial 2x2 (Hayes, 2018).

Pada Tabel 3 menunjukkan hasil analisis lanjutan dengan analisis moderasi sub-kelompok. Sebelumnya, data 
Tabel 2. Hasil analisis regresi linier terhadap variabel prediktor, moderator, dan kriteria

\begin{tabular}{|c|c|c|c|c|c|c|c|c|}
\hline & \multicolumn{8}{|c|}{ Regulasi diri dalam praktik makan (Y) } \\
\hline & \multicolumn{4}{|c|}{ Respon kenyang $\left(Y_{1}\right)$} & \multicolumn{4}{|c|}{ Respon lapar $\left(Y_{2}\right)$} \\
\hline & Coeff & SE & $t$ & $p$ & Coeff & SE & $t$ & $p$ \\
\hline Langkah 1 Constant & 2.95 & 0.22 & 13.53 & 0.00 & 1.78 & 0.19 & 9.23 & 0.00 \\
\hline Praktik pemberian makan yang membatasi & -0.21 & 0.08 & -2.52 & 0.01 & 0.07 & 0.07 & 0.91 & 0.36 \\
\hline Langkah 2 Constant & 2.48 & 0.09 & 27.63 & 0.00 & 1.99 & 0.08 & 25.76 & 0.00 \\
\hline Waktu Layar & -0.01 & 0.02 & -0.78 & 0.44 & 0.00 & 0.01 & -0.52 & 0.61 \\
\hline Langkah 3 Constant & 2.95 & 0.22 & 13.46 & 0.00 & 1.78 & 0.20 & 9.20 & 0.00 \\
\hline Praktik pemberian makan yang membatasi & -0.21 & 0.09 & -2.38 & 0.02 & 0.10 & 0.08 & 1.20 & 0.25 \\
\hline Screen Time & 0.00 & 0.02 & 0.10 & 0.92 & -0.02 & 0.02 & -0.90 & 0.40 \\
\hline Langkah 4 Constant & 2.65 & 0.39 & 6.87 & 0.00 & & & & \\
\hline Praktik pemberian makan yang membatasi & -0.10 & 0.14 & -0.69 & 0.49 & & & & \\
\hline Waktu Layar & 0.09 & 0.10 & 0.95 & 0.35 & & & & \\
\hline $\begin{array}{l}\text { Praktik Pemberian makan yang membatasi \& } \\
\text { waktu layar }\end{array}$ & -0.03 & 0.03 & -0.95 & 0.35 & & & & \\
\hline
\end{tabular}

Catatan: coeff= coefficient; $R^{2}=0.007$, pada langkah 2 untuk satiety responsiveness dan $R^{2}=0.003$ untuk food responsiveness. $R^{2}=0.064$ pada langkah 3 untuk satiety responsiveness dan $R^{2}=0.017$ untuk food responsiveness. $R^{2}=0.07$ pada langkah 4 untuk satiety responsiveness. ${ }^{*} p<0.05$.

diuji menggunakan uji homogenitas Levene dan menunjukkan bahwa data memiliki varian yang sama $F(3,91)=$ $0.14, p=.94$. Praktik pemberian makan yang bersifat membatasi memberikan efek yang signifikan pada respon kenyang $F(1,94)=10.17, p=.002, R^{2}=.10$. Namun, variabel waktu layar tidak memberikan efek yang signifikan $F(1,94)=0.028, p=.87, R^{2}=.00$. Pengaruh waktu layar dalam memoderasi kekuatan hubungan antara praktik pemberian makan yang bersifat membatasi dengan respon kenyang sangat kecil $F(1,94)=0.014, p=$ $.26, R^{2}=.014$ atau hanya mempengaruhi sebesar $1.4 \%$. Gambaran pengaruh variabel moderator dapat dilihat pada Gambar 1.

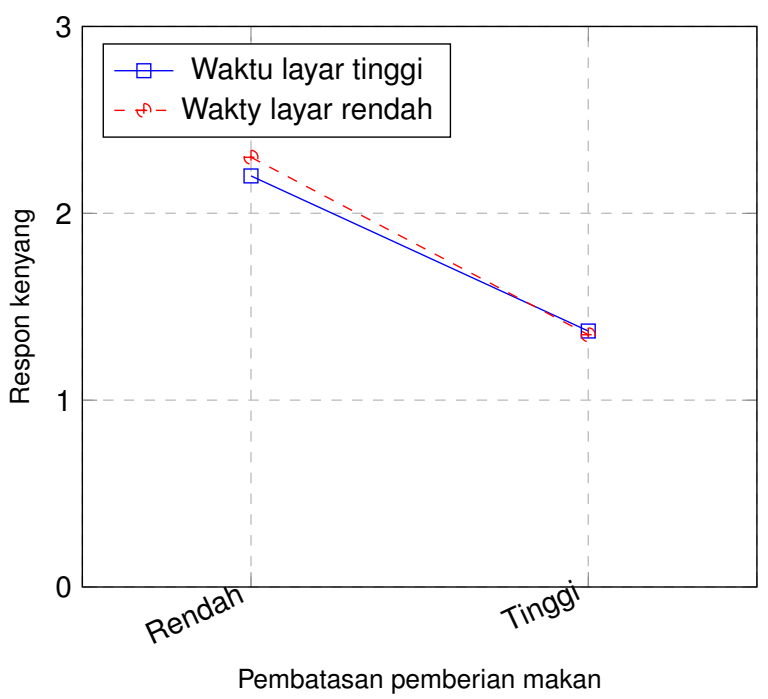

Gambar 1. Pengaruh waktu layer terhadap respon kenyang dengan pembatasan pemberian makan.
Pada Gambar 1 dapat dilihat bahwa anak yang memiliki durasi waktu layar yang rendah maupun tinggi samasama mengalami penurunan skor respon kenyang apabila mendapatkan praktik pemberian makan yang bersifat membatasi yang tinggi. Plot di atas juga menggambarkan bahwa praktik pemberian makan yang bersifat membatasi memberikan pengaruh yang signifikan terhadap respon kenyang anak. Semakin tinggi anak mendapatkan praktik pemberian makan yang bersifat membatasi maka akan semakin menurun skor respon kenyang. Kesimpulan dari interpretasi dari Gambar 1 menunjukkan bahwa hubungan antara praktik pemberian makan yang bersifat membatasi dengan respon kenyang anak tidak dimoderasi secara signifikan oleh berapa lamanya anak menghabiskan waktu dengan gawai atau waktu layar.

\section{Respon Lapar $\left(Y_{2}\right)$}

Hasil untuk variabel respon lapar $\left(Y_{2}\right)$ yang merupakan bagian regulasi diri dalam praktik makan menunjukkan bahwa praktik pemberian makan yang bersifat membatasi tidak berpengaruh secara signifikan terhadap respon lapar $F(1,94)=0.83, p<0.365, R^{2}=0.009$. Pengaruh praktik pemberian makan yang bersifat membatasi terhadap respon lapar $\left(Y_{2}\right)$ ini sangat kecil yaitu kurang dari $1 \%$ dilihat pada nilai $R^{2}=0.009$. Selain itu, hasil yang serupa pada waktu layar yang dihipotesiskan sebagai moderator tidak menunjukkan hasil yang signifikan $F(1,94)=$ $0.27, p<0.61, R^{2}=0.003$. Hasil ini menunjukkan bahwa waktu layar secara signifikan tidak memiliki pengaruh terhadap respon lapar $\left(Y_{2}\right)$. Interaksi antara praktik pemberian makan yang bersifat membatasi dengan waktu layar juga memberikan hasil yang tidak signifikan dalam mempengaruhi respon lapar $\left(Y_{2}\right) F(2,92)=0.82, p<$ $0.45, R^{2}=0.017$. Berdasarkan hasil analisis awal ini 
Tabel 3. Hasil Analisis Moderasi Sub-Kelompok dengan ANOVA Faktorial 2x2

\begin{tabular}{|c|c|c|c|c|c|}
\hline \multirow[b]{2}{*}{ Variabel } & \multicolumn{5}{|c|}{$\begin{array}{l}\text { Regulasi diri dalam praktik makan } \\
\text { (respon kenyang) }\end{array}$} \\
\hline & SS & $d f$ & $\mathrm{R}^{2}$ & $F$ & $p$ \\
\hline Corrected model & 2.60 & 3 & 0.115 & 3.93 & 0.011 \\
\hline Praktik pemberian makan yang membatasi & 2.25 & 1 & 0.101 & 10.17 & 0.002 \\
\hline Screen time & 0.01 & 1 & 0.000 & 0.03 & 0.87 \\
\hline Praktik pemberian makan yang membatasi \& screen time & 0.28 & 1 & 0.014 & 1.27 & 0.26 \\
\hline Error & 20.10 & 9 & - & - & - \\
\hline
\end{tabular}

Catatan: Uji homogenitas menggunakan Levene's Test $F(3,91)=0.14, p=0.94$.

dapat disimpulkan praktik pemberian makan yang bersifat membatasi tidak memiliki pengaruh terhadap respon lapar $\left(Y_{2}\right)$ dan waktu layar bukan variabel moderator yang memoderasi kedua variabel tersebut.

\section{Pembahasan}

Penelitian ini bertujuan untuk mengetahui pengaruh waktu layar terhadap praktik pemberian makan yang bersifat membatasi dengan regulasi diri dalam praktik makan. Regulasi diri dalam praktik makan merupakan kemampuan alami anak untuk mengenali respon internal dari rasa kenyang maupun rasa lapar serta kemampuan memutuskan untuk makan atau tidak makan (Hughes et al., 2016). Pengujian hipotesis pertama berdasarkan hasil analisis awal menunjukkan bahwa praktik pemberian makan yang bersifat membatasi memiliki pengaruh yang signifikan terhadap respon kenyang $\left(Y_{1}\right)$. Respon kenyang menjadi representasi regulasi diri dalam praktik makan yang mengindikasikan bahwa anak menjadi mudah merasa kenyang dan menyisakan makanannya (French et al., 2012). Anak yang sulit makan dan cenderung pilihpilih makanan memiliki skor respon kenyang yang tinggi (Morrison et al., 2013). Sedangkan anak yang pola makannya berlebihan memiliki skor respon kenyang yang rendah (Frankel et al., 2012). Hasil temuan dalam penelitian ini serupa dengan hasil penelitian terdahulu. Temuan dari penelitian sebelumnya menyimpulkan bahwa ibu yang memberikan praktik pemberian makan yang bersifat membatasi dapat membuat anak kurang mampu meregulasi diri dalam praktik makan (Brown, 2011; Farrow et al., 2018; Frankel et al., 2012; Norman et al., 2018). Studi lain juga membuktikan bahwa praktik pemberian makan yang bersifat membatasi ini mengakibatkan peningkatan konsumsi makanan yang dibatasi (Vollmer \& Baietto, 2017; Gibson, 2012; Morrison et al., 2013). Ini diakibatkan orang tua yang membatasi makan anaknya mengajarkan anak untuk mengasosiaikan makan dengan tanda-tanda eksternal sehingga merusak kemampuan anak untuk mengenali tanda internal yang dirasakan seperti tanda lapar dan kenyang. Sehingga, hal ini dapat menghambat kemampuan anak untuk melakukan regulasi diri dalam praktik makan (Brown, 2011; Frankel et al., 2012).
Sedangkan pada analisis lanjutan menyimpulkan bahwa semakin tinggi skor dari praktik pemberian makan anak yang bersifat membatasi, maka skor respon kenyang $\left(Y_{1}\right)$ akan semakin menurun, baik dalam kondisi anak yang memiliki waktu layar yang tinggi maupun rendah. Pada plot Gambar 1 menunjukkan tidak adanya interaksi antara praktik pemberian makan yang bersifat membatasi dengan waktu layar. Sehingga waktu layar atau durasi anak menghabiskan waktu dengan gawai secara signifikan tidak memoderasi hubungan antara praktik pemberian makan yang bersifat membatasi dengan respon kenyang $\left(Y_{1}\right)$. Temuan ini dapat disebabkan oleh beberapa faktor, salah satunya terdapat perbedaan respon anak terhadap respon kenyang $\left(Y_{1}\right)$ saat anak melakukan aktivitas waktu layar. Penelitian oleh Kahardi (2012) menemukan sebanyak $92.7 \%$ anak yang memiliki kebiasaan menonton televisi maupun makan sambil menonton televisi cenderung mengalami kesulitan makan. Anak yang mengalami kesulitan makan ini memiliki skor respon kenyang $\left(Y_{1}\right)$ yang tinggi sebagai representasi regulasi diri dalam praktik makan (Morrison et al., 2013). Studi oleh Kahardi (2012) ini menyimpulkan bahwa kebiasaan menonton televisi maupun makan bersama aktivitas menonton televisi mengakibatkan anak menjadi tidak fokus dengan makanannya sehingga anak seringkali tidak menghabiskan makanan. Namun, studi lain menyebutkan bahwa aktivitas waktu layar maupun makan sambil bermain gawai justru dapat membantu meningkatkan asupan makan anak (Jusiene et al., 2019). Penelitian oleh Syahidah \& Wijayanti (2017) menyimpulkan bahwa balita dengan aktivitas waktu layar yang tinggi memiliki risiko 10.2 kali lebih besar mengalami kegemukan akibat asupan makan yang berlebih dan aktivitas fisik yang kurang. Aktivitas waktu layar yang tinggi mengakibatkan aktivitas fisik anak berkurang, dapat meningkatkan keinginan anak mengonsumsi makanan yang dilihat dari iklan, dan dapat membuat anak menjadi tidak sadar akan banyaknya makanan yang dikonsumsi (Syahidah \& Wijayanti, 2017). Anak dengan asupan makan yang berlebih ini memiliki respon kenyang $\left(Y_{1}\right)$ sebagai representasi regulasi diri dalam praktik makan dengan skor yang rendah (Frankel et al., 2012). Menurut temuan dari kedua penelitian terdahulu ini menghasilkan respon kenyang $\left(Y_{1}\right)$ yang berbeda. Sehingga, aktivitas waktu layar dapat menunjukkan respon 
kenyang $\left(Y_{1}\right)$ yang berbeda-beda yaitu dapat membuat respon kenyang $\left(Y_{1}\right)$ menjadi rendah maupun tinggi. Hasil dari penelitian-penelitian terdahulu ini menjadi alasan yang menguatkan temuan dalam penelitian ini. Sehingga, waktu layar dapat menjadi tidak signifikan pengaruhnya dalam memoderasi hubungan antara praktik pemberian makan yang bersifat membatasi dengan regulasi diri dalam praktik makan anak.

Alasan kedua yang menyebabkan waktu layar bukan moderator adalah data yang terkumpul tidak bervariasi dan didominasi oleh durasi waktu layar anak dengan kategori tinggi. Data yang homogen ini mengindikasikan bahwa sebaran data yang diperoleh memiliki karakteristik yang serupa. Hal ini didukung dengan data waktu layar pada Tabel 1. Rata-rata durasi partisipan menghabiskan waktu menggunakan gawai melebihi batas yang direkomendasikan yaitu 3.7 jam per hari dengan nilai tertinggi 11.6 jam per hari dan nilai terendah sebesar 0.04 jam per hari. Padahal organisasi American Academy of Pediatrics merekomendasikan durasi penggunaan gawai untuk anak usia prasekolah sebesar 1 jam per hari (American Academy of Pediatrics, 2016). Hal ini menggambarkan bahwa data yang diperoleh memiliki kecenderungan waktu layar yang tinggi dan sebaran data yang tidak bervariasi. Temuan data ini selaras dan dapat dijelaskan dengan hasil penelitian sebelumnya yaitu aktivitas waktu layar anak yang tinggi dapat mengakibatkan asupan makan anak meningkat dan meningkatkan risiko kegemukan (Syahidah \& Wijayanti, 2017). Menurut Frankel et al. (2012), anak yang gemuk akibat konsumsi makanan yang berlebih memiliki skor rendah terhadap respon kenyang $\left(Y_{1}\right)$. Penjelasan pada penelitian sebelumnya selaras dengan temuan dalam penelitian ini. Karena data dalam penelitian ini cenderung memiliki kategori waktu layar yang tinggi atau kurang bervariasi datanya, maka waktu layar tidak terbukti berperan sebagai moderator

Analisis pada hipotesis kedua menguji pengaruh waktu layar terhadap hubungan praktik pemberian makan yang bersifat membatasi dengan respon lapar $\left(Y_{2}\right)$. Respon lapar merupakan salah satu dimensi dari regulasi diri dalam praktik makan yang mendeskripsikan sinyal lapar yang dirasakan anak ketika melihat makanan (Hughes et al., 2015). Respon ini mengindikasikan ketertarikan anak pada makanan dan keinginan makan yang besar pada anak saat melihat makanan (French et al., 2012). Interpretasi skor respon lapar $\left(Y_{2}\right)$ berkebalikan dengan respon kenyang $\left(Y_{1}\right)$. Menurut Morrison et al. (2013), anak dengan kesulitan makan dan suka pilih-pilih makan memiliki skor respon kenyang $\left(Y_{1}\right)$ yang tinggi dan respon lapar $\left(Y_{2}\right)$ yang rendah. Pada Tabel 1, data yang terkumpul didominasi dengan rata-rata skor respon lapar $\left(Y_{2}\right)$ yang rendah yang menunjukkan data tidak bervariasi. Hasil analisis awal menyimpulkan bahwa praktik pemberian makan yang bersifat membatasi tidak mempengaruhi respon lapar $\left(Y_{2}\right)$ anak. Apabila dibandingkan dengan penelitian terdahulu, praktik pemberian makan yang bersifat membatasi ini justru dapat meningkatkan konsumsi makanan yang dibatasi yang merefleksikan respon lapar $\left(Y_{2}\right)$ yang tinggi (Vollmer \& Baietto, 2017; Gibson, 2012; Morrison et al., 2013). Karena efek dari pemberian makan yang bersifat membatasi dapat meningkatkan nafsu makan dan memicu otak untuk menginginkan makanan yang dibatasi (Boswell et al., 2018). Temuan yang bertolak belakang dengan penelitian terdahulu ini dapat menjelaskan bahwa prediktor tidak signifikan mempengaruhi variabel kriteria. Berdasarkan hasil analisis awal ini, waktu layar tidak berperan sebagai moderator. Hal ini disebabkan tidak adanya hubungan yang signifikan antara prediktor dan variabel kriteria (Ghozali, 2016).

\section{Simpulan}

Penelitian ini menyimpulkan bahwa waktu layar tidak memoderasi hubungan antara praktik pemberian makan yang bersifat membatasi dengan respon kenyang $\left(Y_{1}\right)$ dan respon lapar $\left(Y_{2}\right)$ yang merepresentasikan regulasi diri dalam praktik makan pada anak prasekolah usia 3-6 tahun. Pada hasil pertama menunjukkan bahwa waktu layar tidak signifikan memoderasi hubungan praktik pemberian makan yang bersifat membatasi dengan respon kenyang $\left(Y_{1}\right)$. Hal ini dapat disebabkan oleh perbedaan respon anak saat melakukan aktivitas waktu layar terhadap respon kenyang $\left(Y_{1}\right)$ dan data yang didominasi dengan waktu layar kategori tinggi sehingga data kurang bervariasi. Temuan ini membuktikan bahwa kebiasaan waktu layar ini justru menghasilkan dua hal yang bertolak belakang. Kebiasaan makan sambil bermain atau menonton hiburan di gawai dilaporkan dapat membantu anak agar mau makan dan hasil lainnya justru membuat anak jadi memiliki masalah makan. Selain itu, data yang diperoleh bersifat homogen atau tidak bervariasi dan durasi rata-rata waktu layar yang cenderung tinggi menguatkan hasil penelitian ini bahwa hipotesis pertama ditolak. Ini merefleksikan bahwa hasil pada penelitian ini menjadi tidak signifikan efek moderasinya.

Sedangkan pada hipotesis kedua, sejak analisis awal menunjukkan bahwa praktik pemberian makan yang bersifat membatasi secara signifikan tidak berpengaruh terhadap respon lapar $\left(Y_{2}\right)$. Hubungan prediktor yang tidak signifikan dengan variabel kriteria ini menjadikan waktu layar tidak dapat berperan sebagai moderator.

\section{Implikasi}

Implikasi yang dapat digunakan bahan pertimbangan setiap orang tua adalah interaksi yang terjadi antara orang tua dengan anak selama praktik makan dan pengaruh lingkungan seperti kebiasaan masyarakat dalam praktik makan anak dapat mempengaruhi kemampuan anak dalam meregulasi diri dalam praktik makan. Praktik pemberian makan yang terlalu membatasi dapat mengganggu regulasi diri anak dalam praktik makan yaitu dapat membuat anak jadi kurang mampu mengenali respon kenyang sehingga 
dapat membuat anak memiliki nafsu makan yang lebih besar dari biasanya.

Pada penelitian ini, ada beberapa kekurangan dan bisa dijadikan pertimbangan untuk penelitian berikutnya. Berdasarkan hasil analisis statistik ditemukan data yang homogen atau kurang bervariasi yaitu data waktu layar. Peneliti menyarankan pada penelitian selanjutnya untuk meningkatkan jumlah partisipan yang akan diteliti sehingga dapat mendapatkan data yang lebih bervariasi. Selain itu, aktivitas waktu layar anak juga perlu diteliti lebih mendalam lagi karena respon aktivitas waktu layar anak terhadap regulasi diri pada perilaku makan dapat memberikan respon yang berbeda. Sehingga, untuk penelitian berikutnya dapat diulas lebih mendalam lagi terkait konten dari aktivitas waktu layar dari tontonan anak seperti iklan makanan yang ditonton anak dan suasana atau kondisi emosional anak saat makan sambil bermain gawai.

\section{Referensi}

American Academy of Pediatrics. (2016). American academy of pediatrics announces new recommendations for children's media use. Retrieved October 16, 2020, from https://services.aap.org/en/news-room/news-releases/aap/ 2016/aap-announces-new-recommendations-for-media-use/

Avery, A., Anderson, C., \& McCullough, F. (2017). Associations between children's diet quality and watching television during meal or snack consumption: A Systematic review. Maternal Child Nutrition, 13(4), 12428. https://doi.org/https: //doi.org/10.1111/mcn.12428

Blissett, J. (2011). Relationship between parenting style, feeding style and feeding practices and fruit and vegetable consumption in early childhood. Appetite, 57(3), 826-831. https://doi.org/10.1016/j.appet.2011.05.318

Brown, J. E. (2011). Nutrition through life cycle. Cengage Learning.

Farrow, C. V., Haycraft, E., \& Blisset, J. M. (2018). Observing maternal restriction of food with 3-5 years old children: Relationship with temperament and later body mass index (BMI). International Journal of Environmental Research and Public Health, 15(6), 1273. http://dx.doi.org/10.3390/ ijerph15061273

Frankel, L. A., Hughes, S. O., Connor, T. M. O., Power, T. G., Fisher, J. O., \& Hazen, N. L. (2012). Parental influences on children' s self-regulation of energy intake: Insights from developmental literature on emotion regulation. Journal of Obesity 2012. https://doi.org/10.1155/2012/327259

Hardy, L. L., Booth, M. L., \& Okely, A. D. (2007). The reliability of the adolescent sedentary activity questionnaire (ASAQ). Preventive Medicine: An International Journal Devoted to Practice and Theory, 45(1), 71-74. https://doi.org/10.1016/j. ypmed.2007.03.014

Hayes, A. F. (2018). Introduction to mediation, moderation, conditional process analysis. The Guilford Press.
Hughes, S. O., Alexis, C., \& F.-W. (2016). Satiety and the selfregulation of food take in children: Potential role for geneenvironment interplay.Curr Obese Rep, 5(1), 81-87. https: //doi.org/10.1007/s13679-016-0194-y

Hughes, S. O., Power, T. G., Connor, T. M. O., Orlet, J., Tower, J., \& Box, P. O. (2015). Executive functioning, emotion regulation, eating self-regulation, and weight status in lowincome preschool children: How do they relate? . Appetite, 89, 1-9. https://doi.org/10.1016/j.appet.2015.01.009

Kementerian Kesehatan RI. (2018). Badan Penelitian dan Pengembangan Kesehatan. Laporan Riset Kesehatan Dasar 2018. Jakarta; Kementerian Kesehatan RI.

Jusiene, R., Urbonas, V., Laurinaityte, I., Rakickiene, L., Breidokiene, R., Kuzminskite, M., \& Prainskiene, R. (2019). Screen use during meals among young children: Exploration of associated variables. Medicina, 55(2019), 688. https://doi. org/10.3390/medicina55100688

Kahardi, E. (2012). Pengaruh konseling dengan "feeding rules" terhadap status gizi anak dengan kesulitan makan. Retrievet from https://core.ac.uk/download/pdf/11735831.pdf

Lafraire, J., Rioux, C., Giboreau, A., \& Picard, D. (2016). Food rejection in children: Cognitive and social/environmental factors involved in food neophobia and picky/fussy eating behavior. Appetite, 96(2016), 347-357. https://doi.org/10. 1016/j.appet.2015.09.008

Morrison, H., Power, T. G., Nicklas, T., \& Hughes, S. O. (2013). Exploring the effects of maternal eating patterns on maternal feeding and child eating. Appetite, 63(2013), 77-83. /http: //dx.doi.org/10.1016/j.appet.2012.12.017

Musher-Eizenman, Dara \& Holub, S. (2007). Comprehensive feeding practices questionnaire: Validation of a new measure of parental feeding practices. Journal of Pediatric Psychology, 32(8), 960-972. http://dx.doi.org/10.1093/jpepsy/ jsm037

Norman, J., Kelly, B., McMahon, A., Boylan, E., Baur, L. A., Chapman, K., King, L., Hughes, C., \& Bauman, A. (2018). Children's self-regulation of eating provides no defense against television and online food marketing. Appetite, 125(2018), 438-444. https://doi.org/10.1016/j.appet.2018. 02.026

Pavilianingtyas, A. (2017). Faktor agen, pejamu, dan lingkungan kejadian obesitas pada anak usia 5-6 tahun. Jurnal Gizi Indonesia, 5(2), 105-111. https://doi.org/10.14710/jgi.5.2. 105-111

Pearson, N., Biddle, S. J. H., Griffiths, P., Johnston, J. P., \& Haycraft, E. (2018). Clustering and correlates of screen-time and eating behaviours among young children. BMC Public Health, 18, 753. https://doi.org/10.1186/s12889-018-5698-9

Rifani, R., Suryanto, \& Suminar, D. R. (2019). Maternal feeding strategy used by working mothers of children 4-6 years old. Advances in Social Science Education and Humanities Research (ASSEHR), 227, 564-567. http://dx.doi.org/10. 2991/icamr-18.2019.134

Santrock, J. W. (2014). Child development (14th ed.). McGrawHill. 
Syahidah, Z.A., \& Wijayanti, H.S. (2017). Perbedaan aktivitas fisik, screen time, dan persepsi ibu terhadap kegemukan antara balita gemuk dan non-gemuk di kota Semarang. Journal of Nutrition College, 6(1), 11-18. https://doi.org/10. 14710/jnc.v6i1.16886

Subardjo, Y. P., Sudargo, T., \& Julia, M. (2013). Paparan iklan televisi terhadap pemilihan makanan dan asupan pada anak. Jurnal Gizi Klinik, 19(2), 101-110. https://doi.org/10.22146/ ijen. 18852

Sumarwan, U., Simanjutak, M., \& Y. (2012). Persepsi dan preferensi iklan mempengaruhi niat beli anak pada produk makanan ringan. Jurnal Ilmu Keluarga \& Konsumen, 5(2), 185-192. https://doi.org/10.24156/jikk.2012.5.2.186

Tan, C. C., \& Holub, S. C. (2010). Children's self-regulation in eating: Association with inhibitory control and parent feeding behaviour. Journal of Pediatric Psychology, 36(3), 340-345. http://dx.doi.org/10.1093/jpepsy/jsq089

Vollmer, R. L., \& Baietto, J. (2017). Practices and preferences: Exploring the relationships between food-related parenting practices and child food preferrences for high fat and/ or sugar foods, fruits, and vegetables. Appetite, 113(2017), 134-140. http://dx.doi.org/10.1016/j.appet.2017.02.019

Wardle, J., Guthrie, C. A., Sanderson, S., \& Rapoport, L. (2001). Development of the Children's Eating Behaviour Question- naire. Journal of child psychology and psychiatry, and allied disciplines, 42(7), 963-970. https://doi.org/10.1111/14697610.00792

Boswell N, Byrne R, Davies PSW. (2018). Eating behavior traits associated with demographic variables and implications for obesity outcomes in early childhood. Appetite, 120, 482-490. https://doi.org/10.1016/j.appet.2017.10.012.

French, S.D., Green, S.E., O'Connor, D.A. et al. (2012). Developing theory-informed behaviour change interventions to implement evidence into practice: A systematic approach using the Theoretical Domains Framework. Implementation Science, 7(38), 1-8. https://doi.org/10.1186/1748-5908-7-38 Sugiyono. 2004. Metode Penelitian Bisnis. Alfabeta.

Ghozali, I. (2016). Aplikasi Analisis Multivariete dengan Program IBM SPSS 23(VIII). Badan Penerbit Universitas Diponegoro.

The Asian Parent Insight. (2014). Mobile Device Usage Among Young Kids. Singapore: Samsung KidsTime. Retrieved from https://s3-ap-southeast-1.amazonaws.com/tapsg-media/theAsianparent+Insights+Device+Usage+A+ Southeast+Asia+Study+November+2014.pdf

Gibson, E. L. (2012). The psychobiology of comfort eating: implications for neuropharmacological interventions. Behavioural Pharmacology, 23, 442-460. 